\title{
PENGARUH KOMPENSASI, PENDIDIKAN DAN PELATIHAN, PROGRAM KESELAMATAN DAN KESEHATAN KERJA TERHADAP KINERJA KARYAWAN BPBD TABANAN
}

\author{
Made Marsha Bayu Kresna ${ }^{1}$ \\ I Wayan Suana ${ }^{2}$
}

\author{
${ }^{1,2}$ Fakultas Ekonomi dan Bisnis Universitas Udayana (Unud), Bali, Indonesia \\ e-mail: marshamanualtech@yahoo.com
}

\begin{abstract}
ABSTRAK
Kesiapsiagaan bencana di Indonesia masih tergolong rendah dibandingkan negara lainnya di dunia. Maka dari itu, pencegahan dan kesiapsiagaan karyawan Badan Penanggulangan Bencana Daerah (BPBD) harus ditingkatkan, khususnya di daerah Tabanan. Tujuan penelitian ini adalah untuk menganalisis kompensasi, pendidikan dan pelatihan, program keselamatan dan kesehatan kerja terhadap kinerja karyawan Badan Penanggulangan Bencana Daerah Tabanan. Populasi dalam penelitian ini adalah seluruh karyawan di Badan Penanggulangan Bencana Daerah yang berjumlah 80 orang tetapi yang digunakan sebagai koresponden berjumlah hanya 42 orang. Data yang dikumpulkan pada penelitian ini dianalisis dengan menggunakan analisis regresi linear berganda. Hasil analisis dalam penelitian ini menunjukkan bahwa : Kompensasi berpengaruh positif dan signifikan terhadap Kinerja pegawai di Badan Penanggulangan Bencana Daerah Tabanan, Pendidikan dan pelatihan berpengaruh positif dan signifikan terhadap kinerja pegawai Badan Penanggulangan Bencana Daerah Tabanan, dan Program keselamatan dan kesehatan kerja berpengaruh positif dan signifikan terhadap kinerja pegawai di BPBD Tabanan.

Kata Kunci: kompensasi, pendidikan dan pelatihan, program keselamatan dan kesehatan kerja, kinerja karyawan
\end{abstract}

\begin{abstract}
Disaster preparedness in Indonesia is still relatively low compared to other countries in the world. Therefore, prevention and preparedness of the Regional Disaster Management Agency (BPBD) must be improved, especially in the Tabanan area. The purpose of this study was to analyze compensation, education and training, occupational safety and health programs on the employee performance of the Tabanan Regional Disaster Management Agency. The population in this study were all employees in the Regional Disaster Management Agency which numbered 80 people but only 42 people were used as correspondents. Data collected in this study were analyzed using multiple linear regression analysis. The results of the analysis in this study indicate that: Compensation has a positive and significant effect on employee performance at the Tabanan Regional Disaster Management Agency, Education and training has a positive and significant effect on the performance of the Tabanan Regional Disaster Management Agency employees, and the occupational health and safety program has a positive and significant impact on employee performance at Tabanan BPBD.

Keywords: compensation, education and training, occupational safety and health programs, employee performance
\end{abstract}




\section{PENDAHULUAN}

Indonesia memiliki tantangan yang cukup besar dalam menyikapi keadaan geografis wilayahnya. Berdasarkan hal tersebut berbagai daerah di Indonesia memiliki ancaman terhadap terjadinya suatu bencana. Indonesia juga dikenal sebagai Negara paling rawan bencana dibandingkan dengan negara lainnya di dunia. Menurut suatu Badan PBB yang membidangi resiko bencana yaitu UNISDR (United Nations International Strategy for Disaster Reduction), Indonesia menduduki peringkat teratas untuk beberapa jenis bencana alam yang dilihat dari korban meninggal dunia akibat bencana tersebut, dapat diartikan bahwa kesiapsiagaan bencana di Indonesia masih tergolong rendah dibandingkan negara lainnya di dunia. Maka dari itu, pencegahan dan kesiapsiagaan karyawan Badan Penanggulangan Bencana Daerah harus ditingkatkan, khususnya di daerah Tabanan.

Tabel 1.

Rekapitulasi Bencana yang Ditangani BPBD Kabupaten Tabanan Tahun 2018

\begin{tabular}{clc}
\hline No. & \multicolumn{1}{c}{ Jenis Bencana } & Jumlah Kejadian \\
\hline 1. & Tanah Longsor & 104 \\
2. & Pohon Tumbang & 23 \\
3. & Orang Tengelam & 1 \\
\hline & Jumlah & 128 \\
\hline
\end{tabular}
Sumber: BPBD Kabupaten Tabanan 2018

Tabel 1 memperlihatkan bahwa bencana yang terjadi di wilayah Kabupaten Tabanan tidak dapat diprediksi tingkat kejadiannya. Dalam pelaksanaannya tentu saja terdapat kendala sehingga hasil yang diinginkan belum maksimal. Maka dari itu, dalam manajemen pemerintahaan di BPBD kabupaten Tabanan, perlu melakukan suatu evaluasi kinerja. Dimana selanjutnya akan menimbulkan 
Made Marsha Bayu Kresna dan I Wayan Suana, Pengaruh Kompensasi, Pendidikan...

pertanyaan bagaimana sebenarnya keberhasilan BPBD dalam pelaksanaan bidang pencegahan dan kesiapsiagaan bencana.

Sumber daya manusia merupakan sumber daya yang digunakan untuk mensinergikan sumber daya lainnya untuk tujuan organisasi (Heather et al., 2009). Tanpa SDM, sumber daya lainnya menganggur dan kurang bermanfaat dalam mencapai tujuan organisasi (Andre et al., 2007). Peran karyawan sangat besar dalam mencapai keberhasilan perusahaan, hal yang perlu dipertimbangkan adalah performance karyawan yaitu pelayanan. Keberhasilan suatu perusahaan ditentukan oleh pelayanan yang diberikan. Setiap perusahaan tentu selalu meningkatkan performance karyawannya, dengan harapan tujuan perusahaan juga tercapai (Siagian, 2007:76).

Kinerja karyawan adalah salah satu faktor yang mempengaruhi tingkat keberhasilan suatu organisasi atau perusahaan. Kinerja karyawan merupakan suatu tindakan yang dilakukan karyawan dalam melaksanakan pekerjaan yang diberikan perusahan (Handoko, 2009:135). Rivai (2010:547) menyatakan bahwa didalam dunia usaha berkompetisi secara global, perusahaan memerlukan kinerja tinggi. Salah satu faktor yang mempengaruhi kinerja karyawan adalah kompensasi. Kompensasi merupakan faktor yang penting bagi perusahaan karena kompensasi dapat menarik, memelihara dan mempertahankan tenaga kerja serta mendorong tenaga kerja untuk produktif. Secara umum tujuan manajemen kompensasi adalah untuk membangun perusahaan mencapai tujuan keberhasilan strategi perusahaan dan manjamin terciptanya eksternal dan internal. 
Berdasarkan observasi yang dilakukan, Dinas memiliki pegawai tetap, dan pegawai kontrak, serta mahasiswa magang atau praktek kerja lapangan (PKL). Karyawan tetap dan kontrak diperusahaan ini diberikan kompensasi yang berupa gaji, tunjangan, masa kerja, serta kemampuan masing-masing setiap pegawai. Dalam pemberian kompensasi terkadang menimbulkan kecemburuan sosial antara pegawai satu dengan lainnya, jika pemberian kompensasi tersebut tidak adil dan baik, yang akan mengakibatkan menurunnya tingkat kinerja pada karyawan yang merasa tidak diberlakukan adil dalam pemberian kompensasi. Kompensasi yang adil lebih mungkin untuk menarik, mengembangkan, memotivasi dan mempertahankan pegawai yang berkualitas dan kompeten (Quartey, 2013). Kondisi tersebut akan mengakibatkan pegawai tidak produktif dalam bekerja dan ber implikasi pada semangat kerja. Oleh karena itu pemberian kompensasi yang adil dan benar sangat berpengaruh terhadap kinerja pegawai, karena dalam pemberian kompensasi yang adil dan benar akan meningkatkan prosuktivitas karyawn dalam melaksanakan pekerjan.

Kinerja juga dapat dipengaruhi oleh pendidikan dan pelatihan kerja. Pendidikan dan pelatihan (diklat) sesugguhnya tidak sama, walaupun banyak persamaannya yaitu keduanya berhubungan erat dengan pemberian bantuan kepada karyawan agar karyawan tersebut dapat berkembang ke tingkat kecerdasan, pengetahuan dan kemampuan yang lebih tinggi (Hasibuan, 2001:83). Gomes (2003:197) mengemukakan pelatihan adalah setiap usaha untuk memperbaiki performansi pekerja pada suatu pekerjaan tertentu yang sedang menjadi tanggung jawabnya. Sarboland (2012:2695) dalam penelitiannya 
Made Marsha Bayu Kresna dan I Wayan Suana, Pengaruh Kompensasi, Pendidikan...

menemukan bahwa pendidikan dan pelatihan berpengaruh pada kemampuan karyawan pribadi dan kemampuan organisasi, tingkat pengetahuan mereka, pengetahuan profesional mereka sehingga meningkatkan kinerjanya.

Simanungkalit (2011:9) menyatakan bahwa pendidikan dan pelatihan karyawan merupakan suatu persyaratan pekerjaan untuk memperbaiki penguasaan berbagai keterampilan, keahlian dan pengetahuan berdasarkan aktivitas kerja yang sesungguhnya terinci dan rutin agar dapat menjalankan dan menyelesaikan pekerjaan yang diberikan. Sahinidis (2008), dalam penelitiannya menjelaskan bahwa efektivitas pelatihan karyawan dirasakan dan menimbulkan kepuasan kerja, motivasi dan komitmen pada perusahaan,yang akhirnya meningkatkan kinerja mereka. Penelitian yang dilakukan oleh Moses (2011) menyebutkan, terdapat hubungan yang sangat tinggi antara pendidikan dan pelatihan dan prestasi kerja serta menyebutkan jenis pelatihan, materi pelatihan dan waktu pelaksanaan pelatihan bila diberikan dengan baik akan meningkatkan kinerja karyawan.

Penelitian yang dilakukan Olaniyan dan Ojo (2008) menyatakan bahwa pelatihan diperlukan untuk staf agar mengaktifkan mereka bekerja kearah tujuan yang diharapkan organisasi. Mursidi (2009) menyatakan tujuan pelaksanaan dari pendidikan dan pelatihan adaah memperbaiki efektifitas dan efisiensi kerja karyawan dalam melaksanakan dan mencapai sasaran program kerja yang telah ditetapkan. Pentingnya program pendidikan da pelatihan tersebut diperkuat oleh Lingga (2011) yang menyatakan bahwa pendidikan dan pelatihan dapat meninggalkan kinerja seorang karyawan didalam perusahaan. Soeprihanto 
(2009:87) menyatakan bahwa program pendidikan dan pelatihan (diklat) dimaksudkan untuk meperbaiki kemampuan baik dalam peningkatan pengetahuan maupun penguasaan teori pengambialn keputusan dalam menghadapi persoalanpersoalan perusahan.

Selain pendidikan dan pelatihan, program keselamatan kerja dan kesehatan kerja juga harus diperhatikan oleh perusahaan. Sementara berkaitan dengan kesehatan kerja, Suma'mur (2009: 67) menyebutkan bahwa kesehatan kerja merupakan salah satu faktor penting dan memiliki pengaruh yang positif dalam mendukung peningkatan kinerja karyawan, demikian halnya dengan Lamm (2009:1) dalam penelitiannya menemukan bahwa kesehatan dan keselamatan kerja memberikan manfaat dalam meningkatkan kinerja karyawan. Perusahaan harus mempertimbangkan kesehatan dan keselamatan karyawan sebagai tanggung jawab sosial perusahaan dan dapat sebagai investasi (Quartey, 2014). Anjani et al. (2014) kesehatan kerja adalah suatu usaha dan aturan untuk menjaga kondisi dari kejadian atau keadaan yang merugikan kesehatan, baik keadaan yang sempurana fisik maupun mental sehingga memungkinakan seseorang dapat bekerja dengan optimal. Apabila kesehatan karyawan dalam kondisi sempurna (tidak sedang sakit), maka dapat menekan frekuensi terjadi kecelakaan kerja. Kesehatan dan keselamatan kerja mencakup berbagai unsur, seperti manajemen, kondisi lingkungan dan tenaga kerja untuk memperkecil tingkat risiko kecelakaan (Tsenawatme, 2013). Rhebergen et al. (2011) menegaskan bahwa perusahaan yang rentan terhadap risiko kecelakaan kerja perlu secara berkesimanbungan mempertahankan keselamatan dan kesehatan karyawan, berkaitan dengan 
Made Marsha Bayu Kresna dan I Wayan Suana, Pengaruh Kompensasi, Pendidikan...

pengetahuan dan kondisi kerja tiap individu. Oleh karena itu pihak perusahaan harus lebih memperhatikan keadaan karyawan di dalam melaksanakan tugasnya terutama yang berkitan dengan keselamatan dan kesehatan, sehingga dapat meningkatkan komitmen dan kinerja karwayan (Indriasari, 2008).

Keselamatan dan kesehatan kerja merupakan faktor yang dapat mempengaruhi kinerja karyawan pada perusahaan. Dengan kurangnya pengetahuan tentang penggunaan alat-alat kerja, dapat menimbulakan terjadinya kecelakaan kerja, kurangnya penghargaan dan kompensasi yang diperoleh karyawan. Dengan adanya indikasi tersebut dapat digunakan sebagai latar belakang permasalahan dalam penelitian ini. Pada BPBD karyawan rentan mengalami kecelakaan kerja pada bagian petugaas lapangan karena bagian ini karyawan berhadapan langsung dengan alam maka secara tidak langsung karyawan lebih sering sakit.

Berdasarkan definisi dan kajian teori dari beberapa para ahli yang ada, maka dapat disusun suatu kerangkan konseptual sebagai dasar penentu hipotesis seperti pada Gambar 1.

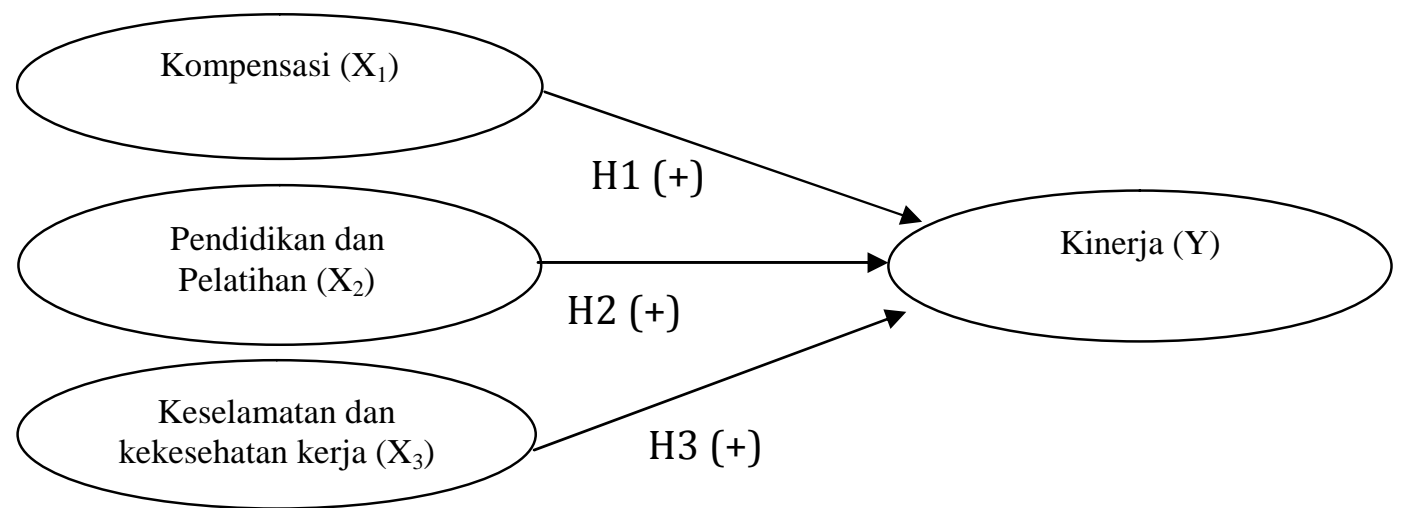

\section{Gambar 1. Desain Penelitian}

Sumber : $\quad \mathrm{H}_{1}$ : Simamora (2009), Prasetya dan Kato (2011), Wekesa (2013)

$\mathrm{H}_{2}$ : Notoatmodjo (2013), Sarboland (2012), Sultana (2012)

$\mathrm{H}_{3}$ : Tawiah (2012, Yusuf (2012), Lamm (2009) 
Berdasarkan desain penelitian pada Gambar 1 dan kajian penelitian terdahulu, maka hipotesis dalam penelitian ini adalah sebagai berikut :

$\mathrm{H}_{1}$ : Kompensasi berpengaruh positif terhadap kinerja karyawan.

$\mathrm{H}_{2}$ : Program pendidikan dan pelatihan kerja berpengaruh positif pada peningkatan kinerja karyawan

$\mathrm{H}_{3}$ : Program keselamatan kesehatan kerja berpengaruh positif pada kinerja karyawan

\section{METODE PENELITIAN}

Penelitian ini digolongkan pada penelitian asosiatif (hubungan), yaitu suatu penelitian yang bertujuan mengetahui pengaruh sebab akibat dari variabel-varibel yang di teliti (Sugiyono,2009:5). Objek penelitian dalam penelitian ini berkaitan dengan kinerja karyawan yang difokuskan pada teori kompensasi, pendidikan dan pelatihan kerja, serta kesehatan dan keselamatan kerja. Lokasi penelitian ini dilakukan pada Badan Penanggulangan Bencana Daerah sesuai dengan alasanalasan yang tertera pada bagian sebelumnya. Selain itu pemilihan lokasi ini didasarkan adanya narasumber dan data yang cukup mampu di olah oleh peneliti.

Populasi yang digunakan dalam penelitian ini adalah karyawan Badan Penanggulangan Bencana Daerah Tabanan, jumlah populasi di BPBD Tabanan berjumlah 80 orang. Sampel penelitian ini diambil secara purposive sampling yaitu suatu metode penarikan sampel probabilitas yang dilakukan dengan kriteria tertentu. Sampel yang digunakan sebanyak 42 orang yang merupakan petugas lapangan di BPBD.

Penelitian ini menggunakan dua jenis variabel yaitu variabel bebas, dan variabel terikat, yang secara rinci dirangkum dalam Tabel 2. 
Tabel 2.

Rangkuman Variabel dan Indikator Penelitian

\begin{tabular}{|c|c|c|c|}
\hline No. & Variabel & Indikator & Referensi \\
\hline 1. & $\begin{array}{l}\text { Kompensasi } \\
\text { (X1) }\end{array}$ & $\begin{array}{ll}\text { 1. } & \text { Insentif (X.1.1) } \\
\text { 2. } & \text { Gaji (X.1.2) } \\
\text { 3. } & \text { Tunjangan-tunjangan (X.1.3) } \\
\text { 4. } & \text { Bonus (X.1.4) }\end{array}$ & Farid(2008) \\
\hline 2. & $\begin{array}{l}\text { Pendidikan } \\
\text { dan Pelatihan } \\
\text { Kerja (X2) }\end{array}$ & $\begin{array}{ll}\text { 1. } & \text { Manfaat diklat (X.2.1) } \\
\text { 2. } & \text { Materi diklat (X.2.2) } \\
\text { 3. } & \text { Motivasi (X.2.3) } \\
\text { 4. } & \text { Informasi diklat (X.2.3) }\end{array}$ & $\begin{array}{l}\text { Ardianta, } \\
\text { (2014) }\end{array}$ \\
\hline 3. & $\begin{array}{l}\text { Kesehatan } \\
\quad \text { dan } \\
\text { Keselamatan } \\
\text { Kerja (X3) }\end{array}$ & $\begin{array}{ll}\text { 1. } & \text { Kondisi kerja yang aman (X.3.1) } \\
\text { 2. } & \text { Pelayanan karyawan (X.3.2) } \\
\text { 3. } & \text { Lingkungan kerja yang sehat (X.3.3) } \\
\text { 4. } & \text { Pelayanan kesehatan (X.3.4) }\end{array}$ & $\begin{array}{l}\text { Sholihah dan } \\
\text { Kuncoro, } \\
(2014: 30)\end{array}$ \\
\hline 4. & $\begin{array}{l}\text { Kinerja } \\
\text { Karyawan } \\
\text { (Y) }\end{array}$ & $\begin{array}{ll}\text { 1. } & \text { Prestasi kerja (Y1) } \\
\text { 2. } & \text { Tanggung jawab (Y2) } \\
\text { 3. } & \text { Meminimalkan kesalahan pekerjaan (Y3) } \\
\text { 4. } & \text { Kerjasama (Y4) } \\
\text { 5. } & \text { Inisiatif (Y5) } \\
\text { 6. } & \text { Ketepatan waktu (Y6) }\end{array}$ & $\begin{array}{l}\text { Sedarmayanthi } \\
(2010: 63)\end{array}$ \\
\hline
\end{tabular}

Sumber: Kajian penelitian sebelumnya, 2018

Penelitian ini menggunakan 9 indikator sehingga dengan menggunakan estimasi berdasarkan jumlah parameter diperoleh ukuran sampel sebesar 45 - 90 responden. Berdasarkan pertimbangan tersebut maka ukuran sampel dalam penelitian ini ditetapkan sebanyak 90 responden.

Data dalam penelitian ini dikumpulkan melalui instrumen penelitian berupa kuesioner. Data yang sudah terkumpul, kemudian diuji kelayakannya dengan menggunakan uji validitas dan uji reliabilitas. Data yang sudah dinyatakan layak selanjutnya dianalisis menggunakan analisis statistik deskriptif, dan uji asumsi klasik sebagai uji prasayat sebelum melakukan uji regresi.

Teknik analisis data dalam penelitian ini dengan menggunakan teknik analisis linear berganda. Pengaruh variable dependen terhadap variable independen diuji dengan tingkat kepercayaan 95\% atau $\alpha=5 \%$. Model analisis linear berganda dengan menggunakan persamaan sebagai berikut : 
$\mathrm{Y}=\alpha+\beta_{1} \mathrm{X}_{1}+\beta_{2} \mathrm{X}_{2}+\beta_{3} \mathrm{X}_{3}+\mathrm{e}$

Keterangan :

$\begin{array}{ll}\mathrm{Y} & =\text { Kinerja Karyawan } \\ \alpha & =\text { Konstanta } \\ \beta_{1}, \beta_{2}, \beta_{3} & =\text { Koefisien Regresi Variabel Independen } \\ \mathrm{X} 1 & =\text { Kompensasi } \\ \mathrm{X} 2 & =\text { Pendidikan dan Pelatihan } \\ \mathrm{X} 3 & =\text { Kesehatan dan Keselamatan Kerja } \\ \mathrm{e} & =\text { Error / Variabel lain yang tidak teridentifikasi dalam model }\end{array}$

\section{HASIL DAN PEMBAHASAN}

Data penelitian diperoleh dari hasil kuesioner yang telah disebarkan kepada responden penelitian sejumlah 42 orang pegawai tetap yang bekerja di Badan Penanggulangan Bencana Daerah Tabanan. Karakteristik responden meliputi umur, jenis kelamin, dan lama bekerja responden. Ringkasan mengenai karakteristik responden dapat dilihat pada Tabel 3 sebagai berikut:

Tabel 3.

Karakteristik Pegawai BPBD Tabanan

\begin{tabular}{|c|c|c|c|c|}
\hline No & Karakteristik & Klasifikasi & $\begin{array}{c}\text { Jumlah Responden } \\
\text { (orang) }\end{array}$ & $\begin{array}{c}\text { Responden } \\
(\%)\end{array}$ \\
\hline \multirow{4}{*}{1} & \multirow{3}{*}{ Umur } & 18 - 28 Tahun & 13 & 30.95 \\
\hline & & 29-38 Tahun & 21 & 50.00 \\
\hline & & $>39$ Tahun & 8 & 19.05 \\
\hline & \multicolumn{2}{|c|}{ Jumlah } & 42 & 100 \\
\hline \multirow{3}{*}{2} & \multirow{2}{*}{ Jenis Kelamin } & Laki-laki & 38 & 90.48 \\
\hline & & Perempuan & 4 & 9.52 \\
\hline & \multicolumn{2}{|c|}{ Jumlah } & 42 & 100 \\
\hline \multirow{6}{*}{3} & \multirow{5}{*}{ Lama Kerja } & $\leq 1$ tahun & 5 & 11.90 \\
\hline & & 1- 2 tahun & 10 & 23,81 \\
\hline & & $2-3$ tahun & 13 & 30.95 \\
\hline & & $3-4$ tahun & 8 & 19,05 \\
\hline & & $\geq 5$ tahun & 6 & 14,29 \\
\hline & \multicolumn{2}{|c|}{ Jumlah } & 42 & 100 \\
\hline
\end{tabular}

Sumber : Hasil pengolahan data primer, 2018

Tabel 3 menunjukkan bahwa mayoritas pegawai yang bekerja di Badan

Penanggulangan Bencana Daerah Tabanan berumur 29-38 tahun dan dominan 
Made Marsha Bayu Kresna dan I Wayan Suana, Pengaruh Kompensasi, Pendidikan...

adalah pegawai laki-laki dengan persentase 90,48 persen, sedangkan pegawai perempuan sebanyak 4 orang atau 9,52 persen. Artinya lebih banyak pegawai laki-laki dibandingkan perempuan yang bekerja di Badan Penanggulangan Bencana Daerah Tabanan. Hal ini disebabkan karena BPBD Tabanan lebih cenderung mencari pegawai laki-laki sebab pekerjaannya yang lebih beresiko dan berbahaya.

Pengelompokkan responden berdasarkan lama kerja menunjukkan bahwa sebagian besar pegawai di Badan Penanggulangan Bencana Daerah Tabanan memiliki masa kerja 1 sampai 3 tahun. Hal ini ada indikasi yang menunjukkan bahwa sering terjadi pengunduran diri dari karyawan, sehingga tidak mampu bertahan kerja hingga lebih dari 3 tahun.

Hasil pengujian instrumen dalam penelitian ini dilakukan dengan menggunakan uji validitas dan reliabilitas dengan hasil yang dapat dilihat pada Tabel 4. Hasil uji pada tabel 4 menunjukkan bahwa seluruh instrumen penelitian yang digunakan untuk mengukur variabel kompensasi, pendidikan dan pelatihan, program keselamatan dan kesehatan kerja, serta kinerja pegawai memiliki nilai koefisien korelasi dengan skor total seluruh item pernyataan lebih besar dari 0,30 dan memiliki koefisien Cronbach's Alpha lebih dari 0,60. Hal ini menunjukkan bahwa butir-butir pernyataan dalam instrument penelitian tersebut valid dan reliabel, sehingga layak digunakan untuk penelitian. 
Tabel 4.

Rekapitulasi Hasil Uji Validitas dan Reliabilitas

\begin{tabular}{cccccc}
\hline Variabel & Indikator & $\begin{array}{c}\text { Koefisien } \\
\text { Korelasi }\end{array}$ & $\begin{array}{c}\text { Sig. (2- } \\
\text { tailed })\end{array}$ & $\begin{array}{c}\text { Cronbadh's } \\
\text { Alpha }\end{array}$ & Keterangan \\
\hline \multirow{2}{*}{ Kompensasi } & $\mathrm{X}_{1.1}$ & 0,888 & 0,000 & & \\
$\left(\mathrm{X}_{1}\right)$ & $\mathrm{X}_{1.2}$ & 0,872 & 0,000 & 0,840 & Valid dan \\
& $\mathrm{X}_{1.3}$ & 0,896 & 0,000 & & Reliabel \\
& $\mathrm{X}_{1.4}$ & 0,931 & 0,000 & & \\
Pendidikan dan & $\mathrm{X}_{2.1}$ & 0,899 & 0,000 & & Valid dan \\
pelatihan & $\mathrm{X}_{2.2}$ & 0,821 & 0,000 & 0,836 & Reliabel \\
$\left(\mathrm{X}_{2}\right)$ & $\mathrm{X}_{2.3}$ & 0,880 & 0,000 & & \\
& $\mathrm{X}_{2.4}$ & 0,907 & 0,000 & & Valid dan \\
Program & $\mathrm{X}_{3.1}$ & 0,693 & 0,000 & & \\
keselamatan dan & $\mathrm{X}_{3.2}$ & 0,752 & 0,000 & 0,800 & Reliabel \\
kesehatan kerja & $\mathrm{X}_{3.3}$ & 0,779 & 0,000 & & Reliabel \\
$\left(\mathrm{X}_{3}\right)$ & $\mathrm{X}_{3.4}$ & 0,792 & 0,000 & & \\
& $\mathrm{Y}_{1}$ & 0,775 & 0,000 & & \\
& $\mathrm{Y}_{2}$ & 0,820 & 0,000 & & \\
Kinerja (Y) & $\mathrm{Y}_{3}$ & 0,661 & 0,000 & \multirow{2}{*}{0,788} & \\
& $\mathrm{Y}_{4}$ & 0,780 & 0,000 & & \\
& $\mathrm{Y}_{5}$ & 0,665 & 0,000 & & \\
& $\mathrm{Y}_{6}$ & 0,834 & 0,000 & & \\
\end{tabular}

Sumber : Hasil Olahan Data, 2018

Deskripsi jawaban responden menyajikan penilaian responden terhadap setiap butir-butir pertanyaan yang diajukan dalam kuesioner. Skala pengukuran yang dipergunakan mulai dari 1 sampai dengan 5., sehingga dapat disusun kriteria pengukuran sebagai berikut.

Tabel 5.

Kriteria Pengukuran Deskripsi Variabel Penelitian

\begin{tabular}{ccc}
\hline No. & Skala Pengukuran & Kriteria \\
\hline 1 & $1,00-1,80$ & Sangat Rendah \\
2 & $1,81-2,60$ & Rendah \\
3 & $2,61-3,40$ & Sedang \\
4 & $3,41-4,20$ & Tinggi \\
5 & $4,21-5,00$ & Sangat Tinggi
\end{tabular}

Secara rinci hasil penelitian mengenai jawaban responden terhadap variabel kompensasi, pendidikan dan pelatihan, program keselamatan dan kesehatan kerja, serta kinerja pegawai dapat dilihat pada Tabel 6, Tabel 7 dan Tabel 8 berikut. 
Tabel 6.

Deskripsi Jawaban Responden Terhadap Variabel Kompensasi

\begin{tabular}{llccccccc}
\hline \multirow{2}{*}{ No } & \multirow{2}{*}{ Pernyataan } & \multicolumn{9}{c}{ Frekuensi Jawaban Responden } & \multirow{2}{*}{ Rata-Rata } & \multirow{2}{*}{ Kriteria } \\
& & STS & TS & N & S & SS & & \\
\hline 1 & Insentif $\left(\mathrm{X}_{1.1}\right)$ & 1 & 7 & 15 & 15 & 4 & 3,33 & Sedang \\
2 & Gaji $\left(\mathrm{X}_{1.2}\right)$ & 4 & 4 & 19 & 9 & 6 & 3,21 & Sedang \\
3 & Tunjangan-tunjangan $\left(\mathrm{X}_{1.3}\right)$ & 2 & 7 & 15 & 9 & 9 & 3,38 & Sedang \\
4 & Bonus $\left(\mathrm{X}_{1.4}\right)$ & 1 & 8 & 13 & 13 & 7 & 3,40 & Sedang \\
\hline \multicolumn{2}{c}{ Rata-rata keseluruhan variabel kompensasi } & & $\mathbf{3 , 3 3}$ & Sedang \\
\hline
\end{tabular}

Sumber : Hasil Olahan Data, 2018

Hasil analisis deksriptif sebagaimana disajikan pada tabel 6 menunjukkan bahwa variabel kompensasi secara keseluruhan memperoleh nilai rata-rata sebesar 3,33, yang berarti bahwa sebagian besar pegawai merasa jika kompensasi yang diberikan di Badan Penanggulangan Bencana Daerah Tabanan cukup rendah. Dari 4 indikator yang digunakan untuk mengukur kompensasi, maka terdapat 2 indikator yang nilainya berada di atas nilai rata-rata $(3,33)$ variabel kompensasi yaitu indikator tunjangan-tunjangan dan indikator bonus. Dari kedua indikator tersebut, yang memiliki nilai paling tinggi adalah indikator bonus. Hal tersebut disebabkan karena bonus yang diberikan perusahaan membuat pegawai Badan Penanggulangan Bencana Daerah Tabanan semangat dalam melakukan pekerjaan. Namun, apabila BPBD tidak memberikan bonus kepada pegawai, maka pegawai tidak akan semangat dalam bekerja.

Skor rata-rata terendah pada variabel kompensasi terdapat pada indikator gaji dengan nilai rata-rata sebesar 3,21. Indikator gaji sudah memperoleh penilaian yang cukup baik dari pegawai berdasarkan hasil kuesioner, namun masih lebih rendah dari nilai rata-rata variabel kompensasi. Hal tersebut menunjukkan bahwa sebagian besar pegawai BPBD merasa bahwa besarnya gaji yang diterima belum sesuai dengan beban kerja yang diberikan. Oleh karena itu, 
dalam upaya meningkatkan kompensasi menjadi lebih baik, maka Badan Penanggulangan Bencana Daerah Tabanan sebaiknya membuat usulan kepada Pemerintah setempat untuk dapat meningkatkan upah pegawai BPBD yang disesuiakan dengan beban kerja yang diberikan. Apabila kompensasi yang diberikan meningkat, tentu akan membuat oegawai semangat dalam bekerja dan kinerja pegawai BPBD Tabanan akan menjadi lebih baik.

Tabel 7.

Deskripsi Jawaban Responden Terhadap Variabel Pendidikan dan pelatihan

\begin{tabular}{|c|c|c|c|c|c|c|c|c|}
\hline \multirow{2}{*}{ No } & \multirow{2}{*}{ Pernyataan } & \multicolumn{5}{|c|}{ Frekuensi Jawaban Responden } & \multirow{2}{*}{ Rata-Rata } & \multirow{2}{*}{ Kriteria } \\
\hline & & STS & TS & $\mathbf{N}$ & $\mathbf{S}$ & SS & & \\
\hline 1 & Manfaat diklat $\left(\mathrm{X}_{2.2}\right)$ & 1 & 7 & 13 & 12 & 9 & 3,50 & Tinggi \\
\hline 2 & Materi diklat $\left(\mathrm{X}_{2.2}\right)$ & 1 & 7 & 17 & 13 & 4 & 3,29 & Sedang \\
\hline 3 & Motivasi $\left(\mathrm{X}_{2.3}\right)$ & 0 & 9 & 12 & 15 & 6 & 3,43 & Tinggi \\
\hline 4 & Informasi diklat $\left(\mathrm{X}_{2.4}\right)$ & 2 & 8 & 16 & 10 & 6 & 3,24 & Sedang \\
\hline \multicolumn{7}{|c|}{ Rata-rata Skor Variabel Pendidikan \& pelatihan } & $\mathbf{3 , 3 6}$ & Sedang \\
\hline
\end{tabular}

Sumber : Hasil Olahan Data, 2018

Hasil analisis deksriptif sebagaimana disajikan pada tabel 7 menunjukkan bahwa variabel pendidikan dan pelatihan secara keseluruhan memperoleh nilai rata-rata sebesar 3,36, yang berarti bahwa pendidikan dan pelatihan yang diberikan kepada pegawai Badan Penanggulangan Bencana Daerah Tabanan cukup rendah. Dari 4 indikator yang digunakan untuk mengukur pendidikan dan pelatihan, maka terdapat 2 indikator yang nilainya berada di atas nilai rata-rata $(3,36)$ variabel pendidikan dan pelatihan yaitu indikator manfaat diklat dan indikator motivasi. Dari kedua indikator tersebut, yang memiliki nilai paling tinggi adalah indikator manfaat diklat. Hal tersebut disebabkan karena sebagian besar responden menilai bahwa Diklat bermanfaat bagi peningkatan kemampuan dan wawasan pegawai BPBD. Namun, pendidikan dan pelatihan bagi pegawai sangat jarang diberikan oleh Badan Penanggulangan Bencana Daerah Tabanan, 
Made Marsha Bayu Kresna dan I Wayan Suana, Pengaruh Kompensasi, Pendidikan...

sehingga hasil penilaian responden terhadap variabel pendidikan dan pelatihan cukup rendah.

Skor rata-rata terendah pada variabel pendidikan dan pelatihan terdapat pada indikator informasi diklat dengan nilai rata-rata sebesar 3,24. Indikator informasi diklat sudah memperoleh penilaian yang cukup baik dari pegawai berdasarkan hasil kuesioner, namun masih lebih rendah dari nilai rata-rata variabel pendidikan dan pelatihan. Hal tersebut menunjukkan bahwa BPBD Tabanan masih kurang memberikan prioritas informasi diklat kepada karyawannya. Oleh karena itu, dalam upaya meningkatkan pendidikan dan pelatihan pegawai, maka Badan Penanggulangan Bencana Daerah Tabanan sebaiknya membuat program pelatihan dan pengembangan secara rutin bagi seluruh pegawai dan memberikan prioritas informasi diklat kepada pegawainya agar seluruh pegawai mampu menyelesaikan pekerjaan dengan baik.

\section{Tabel 8.}

Deskripsi Jawaban Responden Pada Variabel Program Keselamatan Dan

\begin{tabular}{|c|c|c|c|c|c|c|c|c|}
\hline \multicolumn{9}{|c|}{ Kesehatan Kerja } \\
\hline \multirow{2}{*}{ No } & \multirow{2}{*}{ Pernyataan } & \multicolumn{5}{|c|}{ Frekuensi Jawaban Responden } & \multirow{2}{*}{ Rata-Rata } & \multirow{2}{*}{ Kriteria } \\
\hline & & STS & TS & $\mathbf{N}$ & $\mathbf{S}$ & SS & & \\
\hline 1 & Kondisi kerja yang aman $\left(\mathrm{X}_{3.1}\right)$ & 0 & 5 & 22 & 15 & 0 & 3,24 & Sedang \\
\hline 2 & Pelayanan karyawan $\left(\mathrm{X}_{3.2}\right)$ & 0 & 1 & 18 & 19 & 4 & 3,62 & Tinggi \\
\hline 3 & $\begin{array}{l}\text { Lingkungan kerja yang sehat } \\
\left(\mathrm{X}_{3.3}\right)\end{array}$ & 0 & 0 & 15 & 22 & 5 & 3,76 & Tinggi \\
\hline 4 & Pelayanan kesehatan $\left(\mathrm{X}_{3.4}\right)$ & 0 & 2 & 19 & 16 & 5 & 3,57 & Tinggi \\
\hline
\end{tabular}

Rata-rata Skor Variabel Program keselamatan dan kesehatan kerja $\quad \mathbf{3 , 5 4}$ Tinggi

Sumber : Hasil Olahan Data, 2018

Hasil analisis deksriptif sebagaimana disajikan pada Tabel 8 menunjukkan bahwa variabel program keselamatan dan kesehatan kerja secara keseluruhan memperoleh nilai rata-rata sebesar 3,54, yang berarti bahwa sebagian besar pegawai menilai program keselamatan dan kesehatan kerja pada Badan 
Penanggulangan Bencana Daerah Tabanan sudah berjalan dengan baik. Dari 4 indikator yang digunakan untuk mengukur program keselamatan dan kesehatan kerja, maka terdapat 3 indikator yang nilainya berada di atas nilai rata-rata $(3,54)$ variabel program keselamatan dan kesehatan kerja yaitu indikator pelayanan karyawan, indikator lingkungan kerja yang sehat, dan indikator pelayanan kesehatan. Dari ketiga indikator tersebut, yang memiliki nilai paling tinggi adalah indikator lingkungan kerja yang sehat. Hal ini mengindikasikan bahwa Badan Penanggulangan Bencana Daerah Tabanan saat ini mempunyai lingkungan kerja yang sehat.

Skor rata-rata terendah pada variabel program keselamatan dan kesehatan kerja terdapat pada indikator kondisi kerja yang aman dengan nilai rata-rata sebesar 3,24. Hal ini mengindikasikan bahwa pegawai memiliki perasaan yang tidak aman bekerja di BPBD Tabanan. Hal ini disebabkan karena cukup banyak pegawai yang rentan mengalami kecelakaan kerja pada bagian staff lapangan karena bagian ini pegawai berhadapan langsung dengan alam maka secara tidak langsung pegawai lebih sering sakit. Hal tersebut mempengaruhi mental pegawai lainnya, sehingga menimbulkan perasaan tidak aman saat bekerja. Oleh karena itu, dalam upaya meningkatkan program keselamatan dan kesehatan kerja menjadi lebih baik, maka kepala Badan Penanggulangan Bencana Daerah Tabanan sebaiknya pada saat memberikan program keselamatan dan kesehatan kerja dapat melatih mental seluruh pegawai, agar tidak terpengaruh dengan perasaan takut menghadapi bahaya. Selain itu, kepala BPBD Tabanan sebaiknya meningkatkan perhatiannya kepada seluruh pegawai secara adil terhadap kebutuhan pegawai 
Made Marsha Bayu Kresna dan I Wayan Suana, Pengaruh Kompensasi, Pendidikan...

dalam melaksanakan pekerjaan. Dengan memberikan perhatian dan pengertian pada kebutuhan seluruh pegawai, akan membuat pegawai merasa aman dan nyaman karena diperhatikan oleh pimpinannya, sehingga diharapkan dapat meningkatkan kinerja pegawai menjadi lebih baik.

Tabel 9.

Deskripsi Jawaban Responden Pada Variabel Kinerja

\begin{tabular}{|c|c|c|c|c|c|c|c|c|}
\hline \multirow{2}{*}{ No } & \multirow{2}{*}{ Pernyataan } & \multicolumn{5}{|c|}{ Frekuensi Jawaban Responden } & \multirow{2}{*}{ Rata-Rata } & \multirow{2}{*}{ Kriteria } \\
\hline & & STS & TS & $\mathbf{N}$ & $\mathbf{S}$ & SS & & \\
\hline 1 & Prestasi kerja $\left(\mathrm{Y}_{1}\right)$ & 0 & 6 & 18 & 16 & 2 & 3,33 & Sedang \\
\hline 2 & Tanggung jawab $\left(\mathrm{Y}_{2}\right)$ & 0 & 1 & 24 & 13 & 4 & 3,48 & Tinggi \\
\hline \multirow[t]{3}{*}{3} & $\begin{array}{l}\text { Meminimalkan kesalahan } \\
\text { pekerjaan }\left(\mathrm{Y}_{3}\right)\end{array}$ & 2 & 4 & 15 & 18 & 3 & 3,38 & Sedang \\
\hline & $\operatorname{Kerjasama}\left(\mathrm{Y}_{4}\right)$ & 0 & 1 & 14 & 23 & 4 & 3,71 & Tinggi \\
\hline & Inisiatif $\left(\mathrm{Y}_{5}\right)$ & 0 & 5 & 21 & 15 & 1 & 3,29 & Sedang \\
\hline 4 & Ketepatan waktu $\left(\mathrm{Y}_{6}\right)$ & 0 & 1 & 17 & 19 & 5 & 3,67 & Tinggi \\
\hline \multicolumn{7}{|c|}{ Rata-rata Skor Variabel Kinerja } & 3,47 & Tinggi \\
\hline
\end{tabular}

Sumber : Hasil Olahan Data, 2018

Hasil analisis deksriptif sebagaimana disajikan pada tabel 9 menunjukkan bahwa variabel kinerja secara keseluruhan memperoleh nilai rata-rata sebesar 3,47, yang berarti bahwa sebagian besar pegawai pada Badan Penanggulangan Bencana Daerah Tabanan memiliki kinerja yang tinggi. Dari 6 indikator yang digunakan untuk mengukur kinerja, maka terdapat 3 indikator yang nilainya berada di atas nilai rata-rata $(3,47)$ variabel kinerja yaitu indikator tanggungjawab, indikator kerjasama dan indikator ketepatan waktu. Dari ketiga indikator tersebut, yang memiliki nilai paling tinggi adalah indikator kerjasama. Hal tersebut disebabkan karena pegawai Badan Penanggulangan Bencana Daerah Tabanan sudah melakukan kerja sama yang baik dengan pegawai lainnya. Selain itu, sebagian besar pegawai mampu melakukan pekerjaan dengan tepat waktu, kemudian menyampaikan sesuatu yang sesuai dengan keadaan sebenarnya dan mempunyai tanggung jawab dalam pekerjan yang diberikan, sehingga kinerja 
pegawai pada Badan Penanggulangan Bencana Daerah Tabanan mampu terbentuk dengan baik.

Skor rata-rata terendah pada variabel kinerja terdapat pada indikator inisiatif dengan nilai rata-rata sebesar 3,29. Hal ini mengindikasikan bahwa sebagai besar pegawai BPBD Tabanan belum mampu menyelesaikan tugas dan pekerjaan serta mengambil keputusan dalam keadaan yang mendesak. Oleh karena itu, dalam upaya meningkatkan kinerja pegawai menjadi lebih baik, maka kepala Badan Penanggulangan Bencana Daerah Tabanan sebaiknya rutin memberikan pelatihan dan pendidikan kepada seluruh pegawai secara detail, agar pegawai dapat terlatih dengan baik sehingga mampu menyelesaikan tugas dan pekerjaan serta mampu mengambil keputusan dalam keadaan yang mendesak.

Pengujian data dalam penelitian ini menggunakan analisis regresi linier berganda. Perhitungan koefisien regresi linier berganda dilakukan dengan analisis regresi melalui software SPSS 18.0 for Windows, diperoleh hasil yang ditunjukan pada Tabel 10 .

Tabel 10.

Rangkuman Hasil Analisis Regresi Linier Berganda

\begin{tabular}{|c|c|c|c|c|c|}
\hline \multirow[t]{2}{*}{ Model } & \multicolumn{2}{|c|}{$\begin{array}{c}\text { Unstandardized } \\
\text { Coefficients }\end{array}$} & \multirow{2}{*}{$\begin{array}{c}\text { Standardized } \\
\text { Coefficients }\end{array}$} & \multirow[b]{2}{*}{$\mathrm{t}$} & \multirow[b]{2}{*}{ Sig. } \\
\hline & B & Std. Error & & & \\
\hline (Constant) & 2.547 & 2.216 & & 1.149 & .258 \\
\hline Kompensasi & .303 & .102 & .342 & 2.978 & .005 \\
\hline Pendidikan dan Pelatihan & .323 & .114 & .342 & 2.824 & .008 \\
\hline Program Keselamatan dan & 699 & .154 & .431 & 4.542 & .000 \\
\hline Kesehatan & & & & & \\
\hline R Square & 0,701 & & & & \\
\hline F Statistik & 29,708 & & & & \\
\hline Signifikansi & 0,000 & & & & \\
\hline
\end{tabular}


Made Marsha Bayu Kresna dan I Wayan Suana, Pengaruh Kompensasi, Pendidikan...

Berdasarkan hasil analisis regresi linier berganda seperti yang disajikan pada Tabel 10, maka dapat dibuat persamaan regresi sebagai berikut:

$$
Y=2,547+0,303 X_{1}+0,323 X_{2}+0,699 X_{3}
$$

Nilai koefisien regresi masing-masing variabel bebas bernilai positif dengan nilai signifikansi uji t kurang dari 0,05 . Hal ini menunjukkan bahwa semua variabel bebas memiliki pengaruh positif yang signifikan terhadap variabel terikat. Besarnya pengaruh variabel bebas terhadap variabel terikat yang ditunjukkan oleh nilai determinasi total (R Square) pada Tabel 10 sebesar 0,701 mempunyai arti bahwa sebesar 70,1 persen variasi kinerja pegawai di Badan Penanggulangan Bencana Daerah Tabanan dipengaruhi oleh variasi kompensasi, pendidikan dan pelatihan, serta program keselamatan dan kesehatan kerja, sedangkan sisanya sebesar 29,9\% djelaskan oleh faktor lain yang tidak dimasukkan ke dalam model.

Hasil uji F (Ftest) menunjukkan bahwa nilai signifikansi P value 0,000 yang lebih kecil dari $\alpha=0,05$, ini berarti model yang digunakan pada penelitian ini adalah layak. Hasil ini memberikan makna bahwa seluruh variabel independen mampu memprediksi atau menjelaskan fenomena kinerja pegawai di Badan Penanggulangan Bencana Daerah Tabanan.

\section{Pengaruh Kompensasi Terhadap Kinerja Pegawai}

Salah satu cara manajemen untuk meningkatkan prestasi kerja, memotivasi dan meningkatkan kepuasan kerja para karyawan adalah melalui kompensasi. Kompensasi merupakan keseluruhan balas jasa yang diterima oleh kaeyawan sebagai balas jasa dari pelaksanaan pekerjaan di organisasi dalam bentuk uang 
atau lainnya, yang dapat berupa gaji, upah, bonus, insentif, dan tunjangan (Rachmawati, 2008:146).

Hasil analisis pengaruh kompensasi terhadap kinerja pada Tabel 10 menunjukkan nilai signifikasi sebesar 0,005 dengan nilai koefisien beta 0,303. Nilai Signifikansi $0,005<0,05$ mengindikasikan bahwa $\mathrm{H}_{0}$ ditolak dan $\mathrm{H}_{1}$ diterima. Hasil ini mempunyai arti bahwa kompensasi berpengaruh positif dan signifikan terhadap kinerja pegawai di Badan Penanggulangan Bencana Daerah Tabanan. Semakin tinggi kompensasi yang diberikan kepada pegawai Badan Penanggulangan Bencana Daerah Tabanan maka pegawai akan memiliki semangat dalam bekerja sehingga dapat meningkatkan kinerja pegawai. Begitu pula sebaliknya, semakin rendah kompensasi yang diberikan kepada pegawai Badan Penanggulangan Bencana Daerah Tabanan, maka pegawai tidak memiliki semangat kerja yang baik sehingga kinerja pegawai akan semakin menurun.

Penelitian ini mendukung beberapa hasil penelitian sebelumnya dan konsisten dengan hasil penelitian yang dilakukan oleh Prasetya dan Kato (2011) serta Wekesa (2013) yang memperoleh hasil bahwa kompensasi berpengaruh positif dan signifikan terhadap kinerja pegawai. Apabila kompensasi yang diterima pegawai sesuai dengan pengorbanan yang telah diberikan, maka pegawai akan merasan dihargai dan pada akhirnya akan berdampak pada meningkatnya kinerja pegawai tersebut.

\section{Pengaruh Pendidikan dan pelatihan Terhadap Kinerja Pegawai}

Pendidikan dan pelatihan merupakan suatu faktor yang penting dalam meningkatkan kinerja karena pendidikan dan pelatihan merupakan upaya untuk 
Made Marsha Bayu Kresna dan I Wayan Suana, Pengaruh Kompensasi, Pendidikan...

mengembangkan sumber daya manusia, terutama untuk mengembangkan kemampuan intelektual dan kepribadian manusia. Pendidikan di dalam suatu organisasi adalah suatu proses pengembangan kemampuan ke arah yang diinginkan oleh organisasi yang bersangkutan. Sedangkan pelatihan (training) merupakan bagian dari proses pendidikan, yang tujuannya untuk meningkatkan kemampuan atau keterampilan khusus seseorang atau sekelompok orang (Notoatmodjo, 2013:43).

Hasil analisis pengaruh Pendidikan dan pelatihan terhadap Kinerja pada Tabel 10 menunjukkan nilai Signifikansi sebesar 0,008 dengan nilai koefisien beta 0,323. Nilai Signifikansi $0,008<0,05$ mengindikasikan bahwa $\mathrm{H}_{0}$ ditolak dan $\mathrm{H}_{2}$ diterima. Hasil ini mempunyai arti bahwa pendidikan dan pelatihan berpengaruh positif dan signifikan terhadap kinerja pegawai di Badan Penanggulangan Bencana Daerah Tabanan. Semakin tinggi pendidikan dan pelatihan yang diterima oleh pegawai Badan Penanggulangan Bencana Daerah Tabanan maka kinerja pegawai tersebut juga akan semakin bertambah. Begitu pula sebaliknya, semakin rendah pendidikan dan pelatihan yang diterima oleh pegawai Badan Penanggulangan Bencana Daerah Tabanan, maka semakin rendah tingkat kinerja pegawai tersebut.

Penelitian ini mendukung beberapa hasil penelitian sebelumnya dan konsisten dengan hasil penelitian Sarboland (2012) yang memperoleh hasil bahwa pendidikan dan pelatihan berpengaruh terhadap kinerja. Bila pegawai memiliki pendidikan dan pelatihan yang tinggi, diharapkan akan mampu menyelesaikan tugas dengan cepat dan tepat sehingga kinerja akan semakin meningkat. Penelitian 
ini juga di dukung oleh hasil penelitian Sultana (2012:646) yang memperoleh hasil bahwa semakin tinggi pendidikan dan pelatihan maka semakin tinggi kinerja yang akan dihasilkan pegawai.

\section{Pengaruh Program keselamatan dan kesehatan kerja Terhadap Kinerja}

Meningkatnya kinerja karyawan dipengaruhi oleh keberhasilan pelaksanaan program keselamatan dan kesehatan kerja yang dijalankan (Tawiah, 2012). Keselamatan dan kesehatan kerja adalah proses perlindungan tenaga kerja dari segala risiko kecelakaan atau kerusakan yang bisa terjadi atau timbul dalam lingkungan pekerjaannya. Keselamatan dan kesehatan kerja pegawai perlu diperhatiakan, karena selain dapat menganggu tingkat produktivitas, juga dapat mengganggu kinerja pegawai.

Hasil analisis pengaruh program keselamatan dan kesehatan kerja terhadap kinerja pada Tabel 10 menunjukkan nilai signifikansi sebesar 0,000 dengan nilai koefisien beta 0,699. Nilai signifikansi $0,000<0,05$ mengindikasikan bahwa $\mathrm{H}_{0}$ ditolak dan $\mathrm{H}_{3}$ diterima. Hasil ini mempunyai arti bahwa Program keselamatan dan kesehatan kerja berpengaruh positif dan signifikan terhadap Kinerja pegawai di Badan Penanggulangan Bencana Daerah Tabanan. Semakin baik pelaksanaan program keselamatan dan kesehatan kerja maka akan berpengaruh pada semakin meningkatnya kinerja pegawai di Badan Penanggulangan Bencana Daerah Tabanan. Begitu pula sebaliknya, semakin buruk pelaksanaan program keselamatan dan kesehatan kerja pada Badan Penanggulangan Bencana Daerah Tabanan maka akan berpengaruh pada kinerja pegawai yang semakin menurun. 
Made Marsha Bayu Kresna dan I Wayan Suana, Pengaruh Kompensasi, Pendidikan...

Penelitian ini mendukung beberapa hasil penelitian sebelumnya dan konsisten dengan hasil penelitian yang dilakukan oleh Lamm (2009) yang menunjukkan bahwa kesehatan dan keselamatan kerja memberikan manfaat dalam meningkatkan kinerja karyawan. Hasil penelitian ini juga di dukung oleh Tawiah (2012) dan Yusuf (2012) yang memperoleh hasil bahwa ada pengaruh yang positif dan signifikan antara program keselamatan dan kesehatan kerja terhadap kinerja pegawai.

\section{Implikasi Hasil Penelitian}

Implikasi hasil penelitian ini menekankan pada manfaat nyata dari hasil penelitian ini bagi pihak - pihak yang berkepentingan khususnya bagi organisasi. Berdasarkan hasil penelitian yang diperoleh terdapat beberapa implikasi strategis yaitu pertama, hasil survei menunjukkan bahwa indikator bonus dan tunjangantunjangan menjadi faktor penting dalam meningkatkan persepsi kompensasi yang tinggi bagi pegawai. Dengan adanya tunjangan yang memadai dan bonus yang diberikan Badan Penanggulangan Bencana Daerah Tabanan, membuat pegawai semangat dalam melakukan pekerjaan, sehingga akan memotivasi pegawai BPBD Tabanan untuk bekerja lebih baik.

Kedua, hasil survei menunjukkan bahwa indikator manfaat diklat dan motivasi menjadi faktor penting dalam meningkatkan keberhasilan program pendidikan dan pelatihan pegawai BPBD Tabanan. Hal ini disebabkan oleh karena Diklat sangat bermanfaat bagi peningkatan kemampuan dan wawasan pegawai serta dengan adanya diklat, pegawai BPBD menjadi lebih termotivasi untuk bekerja dengan baik. Ketiga, hasil survei menunjukkan bahwa indikator pelayanan 
karyawan, indikator lingkungan kerja yang sehat, dan indikator pelayanan kesehatan menjadi faktor penting dalam meningkatkan keberhasilan program keselamatan dan kesehatan kerja pegawai BPBD Tabanan. Hal ini disebabkan oleh karena pegawai BPBD Tabanan menyukai lingkungan kerja yang sehat, dan pegawai akan merasa aman bekerja di BPBD Tabanan apabila BPBD selalu memberikan pelayanan terhadap kesehatan dan keselamatan dalam menggunakan alat kerja, serta memberikan pelayanan kesehatan saat terjadi kecelakaan saat bekerja.

Keempat, hasil survei menunjukkan bahwa tinggi rendahnya kinerja pegawai disebabkan oleh indikator kerjasama, ketepatan waktu, dan tanggung jawab. Hal tersebut disebabkan karena pegawai Badan Penanggulangan Bencana Daerah Tabanan sudah melakukan kerja sama yang baik dengan pegawai lainnya. Selain itu, sebagian besar pegawai mampu melakukan pekerjaan dengan tepat waktu, kemudian menyampaikan sesuatu yang sesuai dengan keadaan sebenarnya dan mempunyai tanggung jawab dalam pekerjan yang diberikan, sehingga kinerja pegawai pada Badan Penanggulangan Bencana Daerah Tabanan mampu terbentuk dengan baik.

\section{SIMPULAN DAN SARAN}

Berdasarkan hasil penelitian dan pembahasan sebelumnya maka dapat disimpulkan bahwa kompensasi berpengaruh positif dan signifikan terhadap Kinerja pegawai di Badan Penanggulangan Bencana Daerah Tabanan, pendidikan dan pelatihan berpengaruh positif dan signifikan terhadap kinerja pegawai Badan Penanggulangan Bencana Daerah Tabanan, serta program keselamatan dan 
Made Marsha Bayu Kresna dan I Wayan Suana, Pengaruh Kompensasi, Pendidikan...

kesehatan kerja berpengaruh positif dan signifikan terhadap kinerja pegawai di Badan Penanggulangan Bencana Daerah Tabanan.

Saran yang dapat diberikan berdasarkan hasil penelitian yaitu dalam upaya meningkatkan kompensasi menjadi lebih baik, maka Badan Penanggulangan Bencana Daerah Tabanan sebaiknya membuat usulan kepada Pemerintah setempat untuk dapat meningkatkan upah pegawai BPBD yang disesuiakan dengan beban kerja yang diberikan. Apabila kompensasi yang diberikan meningkat, tentu akan membuat pegawai semangat dalam bekerja dan kinerja pegawai BPBD Tabanan akan menjadi lebih baik. Kemudian untuk meningkatkan pendidikan dan pelatihan pegawai, maka Badan Penanggulangan Bencana Daerah Tabanan sebaiknya membuat program pelatihan dan pengembangan secara rutin bagi seluruh pegawai dan memberikan prioritas informasi diklat kepada pegawainya agar seluruh pegawai mampu menyelesaikan pekerjaan dengan baik.

Selanjunya, dalam upaya meningkatkan program keselamatan dan kesehatan kerja menjadi lebih baik, maka kepala Badan Penanggulangan Bencana Daerah Tabanan sebaiknya pada saat memberikan program keselamatan dan kesehatan kerja dapat melatih mental seluruh pegawai, agar tidak terpengaruh dengan perasaan takut menghadapi bahaya. Selain itu, kepala BPBD Tabanan sebaiknya meningkatkan perhatiannya kepada seluruh pegawai secara adil terhadap kebutuhan pegawai dalam melaksanakan pekerjaan. Dengan memberikan perhatian dan pengertian pada kebutuhan seluruh pegawai, akan membuat pegawai merasa aman dan nyaman karena diperhatikan oleh pimpinannya, sehingga diharapkan dapat meningkatkan kinerja pegawai menjadi lebih baik. 
Lalu, untuk meningkatkan kinerja pegawai menjadi lebih baik, maka kepala Badan Penanggulangan Bencana Daerah Tabanan sebaiknya rutin memberikan pelatihan dan pendidikan kepada seluruh pegawai secara detail, agar pegawai dapat terlatih dengan baik sehingga mampu menyelesaikan tugas dan pekerjaan serta mampu mengambil keputusan dalam keadaan yang mendesak

Hasil dari penelitian ini diharapkan mampu mendorong peneliti-peneliti selanjutnya untuk mengamati faktor-faktor lain yang dapat mempengaruhi kinerja selain kompensasi, pendidikan dan pelatihan, serta program keselamatan dan kesehatan kerja. Penelitian selanjutnya juga diharapkan dapat menambah jumlah sampel penelitian serta memperluas wilayah sampel peneliti, dan dapat melakukan penelitian pada beberapa lembaga pemerintah Provinsi Bali sehingga nanti hasilnya dapat digeneralisasikan untuk lingkup yang lebih luas.

\section{REFERENSI}

Anjani, M., Hamidah N.M. dan Arik P. (2014). Pengaruh Keselamatan dan Kesehatan kerja terhadap Kinerja Karyawan (Studi pada Karyawan Bagian Produksi PT. Internasional Power Mitsui Operation and Maintanance Indonesia (IPMOMI) Paiton). Jurnal Administasri Bisnis. 9 (1). pp: 2-12.

Gomes, C.F. (2003). Manajemen Sumber Daya Manusia. Yogyakarta. Penerbit: CV. Andi Offset.

Handoko, T. H. (2009), Manajemen. Yogyakarta: BPFE.

Hasibuan, M. S. P. (2001). Manajemen Sumber Daya Manusia. Jakarta: PT. Toko Gunung Agung.

Heather K., S. Laschinger, M. Leiter, A. Day and D. Gilin. (2009), Workplace empowerment, invicility, and burnout: impact on staff nurce recruitment and retention outcomes. Journal of Nursing Management 17, 302-311.

Husni, M. (2012). Pengaruh Program K3 dan Kompensasi Terhadap Kinerja Karyawan Pada PT. Wijaya Karya (Persero) Tbk Pekanbaru. Jurnal Fakultas Ekonomi Universitas Muhammadiyah Riau. pp: 1-16. 
Made Marsha Bayu Kresna dan I Wayan Suana, Pengaruh Kompensasi, Pendidikan...

Indriasari, N. (2008). Pengaruh Keselamatan Dan Kesehatan kerja Terhadap Kinerja Karyawan (Studi Pada Karyawan Bagian Produksi PT. Surabaya Agung Industri Pulp \& Kertas). Skripsi. Fakultas Ilmu Administrasi Universitas Brawijaya.

Kato, M., dan Arik P. (2011). The Effect of Finansial dan Nonfinancial Compensation to the Employee Performance. The 2nd International Research Symposium in Service Management h : 381-391.

Moses, M. (2011). Pengaruh Pendidikan dan Pelatihan Penjenjangan Terhadap Prestasi Kerja Pegawai Pada Dinas Koperasi dan UKM Kota Jayapura. Analisis Manajemen, 5(2) : 63-76.

Mursidi. (2009). Pengaruh Pendidikan dan Pelatihan Terhadap Kinerja Karyawan Universitas Muhammadiyah Malang. Jurnal Teknik Industri, 10 (2), h: 191-199.

Notoatmodjo, S. (2013). Pendidikan Dan Perilaku Kesehatan. Rineka Cipta. Jakarta.

Olaniyan, D.A. Ojo, Lucas B. (2008). Staff Training and Development: A Vital Tool For Organizational Effectiveness. European Journal of Scientific Research, 24(3): 326-331.

Prasetya, A. and M. Kato. (2011). The Effect of Financial and Non Financial Compensation to the Employee Performance. International Research Symposium in Service Management Yogyakarta, Indonesia, pp: 382-391.

Quartey, S.H. (2013). Is there a link between compensation packages and job performance in the Ghana police service. Journal of Business Management. 7(44), pp: 4398-4406.

Quartey. S.H., and P. B. Buenar. (2014). Employee Health and Safety Practices: An Exploratory and Comparative Study of the Shipping and Manufacturing Industries in Ghana. Report Information from Pro Quest.

Rachmawati, I.K. (2008). Manajemen Sumber Daya Manusia. Edisi Pertama. Andi Offset. Yogyakarta.

Rhebergen, M. DF. A.F. Lenderink, F. J.H van Dijk and C.T.J. Hulshof. (2011). An online expert network for high quality information on occupational safety and health: crosssectional study of user satisfaction and impact. BMC Medical Informatics and Decision Making.

Rivai. (2010). Manajemen Sumber Daya Manusia untuk Perusahaan. Bandung: PT. Remaja Rosda Karya. 
Sahinidis. (2008). Employee perceived training effectiveness relationship to employee attitudes In The European Industrial. Journal of European Industrial Training, Vol 13, Edisi 9, page 63-76.

Sarboland, K. (2012). Investigating The Influence of In Service Training Among Employees of Universities of Bilesavar and Parsabad. International Research Journal of Applied and Basic Sciences, 3 (2), pp: 2695-2699.

Sedarmayanthi. (2010). Manajemen Sumber Daya Manusia Reformasi Birokrasi dan Manajemen Pegawai Negeri Sipil. Bandung: PT. Refrika Aditama.

Sholihah, Q. dan Kuncoro, W. (2014). Keselamatan Kesehatan Kerja : Konsep, Perkembangan, \& Implementasi Budaya Keselamatan. Jakarta : Penerbit buku Kedokteran EGC.

Simamora, H. (2009). Manajemen Sumber Daya Manusia. Edisi 3. Cetakan 1. Yogyakarta: STIE YKPN.

Simanungkalit, H. (2011). Pengaruh Diklat Teknis dan Motivasi terhadap Kinerja Alumni Balai Diklat Industri Regional I Medan. Tesis Pascasarjana Universitas Sumatera Utara (Tidak dipublikasikan).

Soeprihanto, J. (2009). Penilaian Kinerja dan Pengembangan Karyawan. Yogyakarta: BPEE.

Sopiah. (2013). The Effect of Compensation Toward Job Satisfaction and Job Perfomance of Outsourcing Employees of Syariah Banks in Malang Indonesia. International Learning and Development. 3 (2), pp: 77-91

Sugiyono, H. (2009). Manajemen Sumber Daya Manusia. Edisi 3. Cetakan 1. Yogyakarta: STIE YKPN.

Sultana, A. (2012). Impact of Training on Employee Performance: A Study of Telecommunication Sector in Pakistan. Interdisciplinary Journal of Contemporary Research in Business, 4 (6), pp: 646-661.

Suma'mur, P.K. (2009). Higene Perusahaan dan Kesehatan Kerja. Gunung Agung. Jakarta.

Tawiah, A. (2009). Occupational Health and Safety: Key Issues and Concerns in Ghana Kwesi. International Journal of Business and Social Science, 2 (14), pp: 119-126.

Tsenawatme, A. (2013). Pengaruh Keselamatan Dan Kesehatan Kerja Terhadap Kinerja Karyawan (Studi Pada Departemen Social Outreach \& Local Development (SLD) Dan Community Relations (CR) PT.Freeport 
Made Marsha Bayu Kresna dan I Wayan Suana, Pengaruh Kompensasi, Pendidikan...

Wekesa, J.N. (2013). Effect of Compensation on Performance of Public Secondary School Teachers in Eldoret Municipality Kenya. International Journal of Scientific and Research Publications, 3 (6), pp: 1-4.

Yusuf, R.M. (2012). The Influence of Occupational Safety and Health on Performance with Job Satisfaction as Intervening Variables (Study on the Production Employees in PT Mahakarya Rotanindo, Gresik). American Journal of Economics, pp:136-140. 